\title{
Great Power Politics and
} the Struggle over Austria,

$$
\text { 1945-1955 }
$$

\section{Audrey Kurth Cronin}

Cornell University Press 
Great Power Politics and the Struggle over Austria, 1945-1955 


\section{Cornell Studies in Security Affairs}

Edited by Robert J. Art and Robert Jervis

Citizens and Soldiers: The Dilemmas of Military Service, by Eliot A. Cohen Great Power Politics and the Struggle over Austria, 1945-1955, by Audrey Kurth Cronin

The Wrong War: American Policy and the Dimensions of the Korean Conflict, 1950-1953, by Rosemary Foot

The Soviet Union and the Failure of Collective Security, 1934-1938, by Jiri Hochman

The Warsaw Pact: Alliance in Transition?, edited by David Holloway and Jane M. O. Sharp

The Illogic of American Nuclear Strategy, by Robert Jervis

The Nuclear Future, by Michael Mandelbaum

Conventional Deterrence, by John J. Mearsheimer

The Sources of Military Doctrine: France, Britain, and Germany between the World Wars, by Barry R. Posen

The Ideology of the Offensive: Military Decision Making and the Disasters of 1914, by Jack Snyder

The Militarization of Space: U.S. Policy, 1945-1984, by Paul B. Stares Making the Alliance Work: The United States and Western Europe, by Gregory F. Treverton

The Ultimate Enemy: British Intelligence and Nazi Germany, 1933-1939, by Wesley K. Wark 
Copyright (C) 1986 by Cornell University All rights reserved. Except for brief quotations in a review, this book, or parts thereof, must not be reproduced in any form without permission in writing from the publisher. For information, address Cornell University Press, 124 Roberts Place, Ithaca, New York 14850.

First published 1986 by Cornell University Press.

International Standard Book Number 0-8014-1854-2 Library of Congress Catalog Card Number 85-24326

Printed in the United States of America Librarians: Library of Congress cataloging information appears on the last page of the book.

The paper in this book is acid-free and meets the guidelines for permanence and durability of the Committee on Production Guidelines for Book Longevity of the Council on Library Resources. 
To my parents, Rear Admiral Ronald J. Kurth and E. Charlene Kurth, with gratitude and love 
Digitized by the Internet Archive in 2019 with funding from

The Arcadia Fund 